\title{
LATEKS KARET ALAM UNTUK SOL SEPATU: METODE PEMBUATAN, SIFAT MEKANIK DAN MORFOLOGI
}

\section{NATURAL RUBBER LATEX FOR SHOE SOLE: MANUFACTURING METHOD, MECHANICAL AND MORPHOLOGICAL PROPERTIES}

\author{
Indiah Ratna Dewi*, Herminiwati \\ Balai Besar Kulit, Karet, dan Plastik, Jl. Sokonandi No. 9 Yogyakarta 55166, Indonesia \\ * Penulis korespondensi. Telp.: +62 274 512929, 563939; Fax.: +62 274563655 \\ E-mail: indiah_dardanela@gmail.com
}

Diterima: 20 Agustus 2014 Direvisi: 30 Oktober 2014 Disetujui: 5 November 2014

\begin{abstract}
The objectives of this research were to study the manufacturing method, to obtain the best formula and to study the morphological properties of shoe sole from natural rubber latex. The method was conducted in three stages, namely thermoforming, micropore treatment in water, and vulcanization. Latex shoe sole was made by adding 5 phr nano precipitated calcium carbonate (NPCC) fillers and additional CaCO filler varies from 0, 5, 10, 15, to $20 \mathrm{phr}$. The testing method and quality requirement parameters were using SNI 0778:2009. The best formula was achieved from the combination of $\mathrm{NPCC} / \mathrm{CaCO}$, filler at $5 / 5 \mathrm{phr}$. The mechanical properties obtained were tensile strength of 169,87 kg/ $\mathrm{cm}^{2}$, elongation at break of 648,03\%, hardness of 46,33 shore A, density of 0,93 g/ $\mathrm{cm}^{3}$, abrasion resistance of 346,26 $\mathrm{mm}^{3}, 50 \%$ permanent set of 2,15\%, good flexing and no cracks. All parameters, except hardness, met the quality requirements of ISO 0778:2009.
\end{abstract}

Keywords: natural rubber latex, shoe sole, casting.

\begin{abstract}
ABSTRAK
Tujuan dari penelitian ini adalah untuk mempelajari metode pembuatan sol sepatu dari lateks karet alam dengan cetak tuang, mendapatkan formula terbaik berdasarkan sifat mekanik, serta mempelajari sifat morfologinya. Metode tersebut dilakukan dengan tiga tahap, yaitu pembentukan, perendaman dalam air, dan vulkanisaasi. Sol sepatu lateks dibuat dengan bahan pengisi Nano Precipitated Calcium Carbonate (NPCC) sebanyak 5 phr, dan bahan pengisi tambahan $\mathrm{CaCO}_{3}$ bervariasi mulai dari $0,5,10,15$, dan 20 phr. Pengujian menggunakan metode dan syarat mutu sesuai SNI 0778:2009. Hasil penelitian menunjukkan bahwa formula terbaik yang didapat menggunakan kombinasi bahan pengisi $\mathrm{NPCC} / \mathrm{CaCO}_{3}$ sebesar 5/5 phr. Sifat mekanik yang diperoleh adalah tegangan putus sebesar 169,87 $\mathrm{kg} / \mathrm{cm}^{2}$, perpanjangan putus sebesar $648,03 \%$, kekerasan sebesar 46,33 shore A, ketahanan retak lentur yang baik dan tidak retak, densitas sebesar $0,93 \mathrm{~g} / \mathrm{cm}^{3}$, ketahanan kikis $346,26 \mathrm{~mm}^{3}$, dan perpanjangan tetap $50 \%$ sebesar 2,15\%. Seluruh parameter uji memenuhi syarat mutu SNI 0778:2009, kecuali kekerasannya.
\end{abstract}

Kata kunci: lateks karet alam, sol sepatu, cetak tuang.

\section{PENDAHULUAN}

Indonesia merupakan tiga besar negara produsen karet dunia, bersama Thailand dan Malaysia, dan tergabung dalam International Tripartit Rubber Council (ITRC) yang bertugas menjaga stabilitas harga karet. Namun pada tahun 2014, harga karet dunia menurun tajam, dari US\$ 5,7 per kg menjadi US\$ 1,6 per kg, diprediksi karena intervensi Vietnam di ITRC, karena kemampuan Vietnam menggeser Malaysia menjadi negara terbesar ketiga penghasil karet dunia. Kenyataan ini tentunya sangat memukul sektor pertanian di negara penghasil karet (Nurhayat, 2014). Petani Indonesia sangat terpuruk, sehingga dipandang perlu untuk meningkatkan harga jual karet dengan tidak menjualnya dalam bentuk mentah, melainkan dalam bentuk produk jadi, salah satunya menjadi sol sepatu.

Sol sepatu terbuat dari beberapa bahan, diantaranya adalah kulit, karet dan plastik. 
Diantara bahan-bahan tersebut yang paling banyak dipakai adalah karet, diantaranya karet alam (SIR 3L) dan Etilen Vynil Asetat (EVA) untuk sol ringan (Herminiwati \& Lestari, 2009), karet alam (pale crepe) dan Nitril Butadiena Rubber (NBR) untuk sol karet sepatu pengaman (Yuniari, 2010), dan campuran karet alam (pale crepe) dan EVA (Herminiwati \& Sholeh, 2011). Namun, paten dan penelitian yang ada saat ini selalu menggunakan bahan baku karet padat dalam pembuatannya, baik itu karet alam maupun karet sintetis. Padahal karet dalam bentuk cair, atau sering disebut dengan lateks, dapat pula dibuat menjadi produk sol sepatu. Pada penelitian ini telah dibuat sol sepatu berbahan baku lateks karet alam.

Teknologi pembuatan barang jadi dari lateks karetalam lebih mudah dari sisi teknologi, sehingga sangat berpotensi untuk diterapkan di industri kecil. Teknik pembuatannya dapat dilakukan dengan berbagai metode seperti pencelupan, cetak tuang dan pembusaan, tergantung dari produk yang akan dihasilkan. Metode pencelupan digunakan untuk menghasilkan barang tipis dan berongga, sementara metode pembusaan digunakan untuk menghasilkan busa lateks. Sol sepatu merupakan produk yang tebal dan cukup keras, sehingga teknik yang tepat digunakan dalam pembuatannya adalah cetak tuang. Cetak tuang dilakukan dengan cara menuangkan kompon ke dalam cetakan kemudian dipanaskan hingga mengeras. Fachry dkk. (2012) telah memanfaatkan teknik cetak tuang untuk membuat suvenir berbahan lateks karet alam. Namun, sol sepatu memiliki ketebalan dan kekerasan yang lebih besar dibanding suvenir, sehingga perlu memodifikasi teknik cetak tuang yang telah ada saat ini.

Karet mentah memiliki sifat plastis, dan untuk mengubahnya menjadi elastis perlu dilakukan vulkanisasi. Vulkanisasi lateks karet alam secara konvensional memerlukan bahan kimia pembantu seperti bahan pencepat, bahan penggiat dan bahan pemantap, selain bahan pemvulkanisasi. Tahapan yang diperlukan adalah pemanasan pada suhu 40$50^{\circ} \mathrm{C}$ selama 2-3 hari, dilanjutkan pemanasan pada suhu $70^{\circ} \mathrm{C}$ selama 2 jam dan pemanasan akhir $100^{\circ} \mathrm{C}$ selama 1 jam (Andriyanti dkk., 2010). Proses vulkanisasi tersebut memerlukan waktu yang cukup lama dan akan sangat dipengaruhi oleh ketebalan produk yang akan dibuat. Semakin tebal produk yang akan dibuat, tentu memerlukan waktu yang lebih lama untuk membuat kompon lateks memadat dan mengeras.
Tujuan dari penelitian ini adalah mempelajari metode pembuatan sol sepatu dari lateks karet alam dengan cetak tuang, mendapatkan formula terbaik berdasarkan hasil pengujian sifat mekanik, serta mempelajari sifat morfologinya.

\section{BAHAN DAN METODE \\ Bahan Penelitian}

Bahan penelitian terdiri atas lateks karet alam Sinar Agung (pasaran lokal Yogyakarta) dengan spesifikasi Dry Rubber Content (DRC) 60,08\%, Total Solid Content (TSC) 61\%, Mechanical Stability Times (MST) 600-800, dan Volatile Fatty Acid (VFA) $0,003 \%$. Bahan kimia aditif yang ditambahkan adalah bahan penggiat $\mathrm{ZnO}$ Indoxide yang dibeli dari Bratachem, antioksidan Ionol Bayer, bahan pencepat Zink Dibutyl Dithiocarbamate (ZDBC) Mosanto, bahan pemvulkanisasi sulfur SP-325 Miwon, bahan pengisi $\mathrm{CaCO}_{3}$ lokal dan Nano Precipitated Calcium Carbonate (NPCC) Shengke China ukuran partikel $60 \mathrm{~nm}$, bahan pendispersi Darvan I, dan akuades.

\section{Peralatan Penelitian}

Alat penelitian terdiri atas ball mill, mixer merk Zeppelin tipe CS-B7, oven, penangas air, cetakan sol sepatu, alat-alat pengujian berupa tensile strength tester, DIN abrassion resistance, alat uji retak lentur, alat uji perpanjangan tetap, alat uji kekerasan (shore A hardness tester), densimeter, SEM merek JEOL tipe T330A.

\section{Metode Penelitian}

Penelitian dilakukan di Laboratorium Riset Karet, Balai Besar Kulit, Karet, dan Plastik, Yogyakarta. Tahapan penelitian yang dilakukan adalah komponding lateks, penentuan waktu pemeraman optimum, pencarian teknologi proses cetak tuang yang tepat, penentuan formulasi terbaik dengan variabel jumlah bahan pengisi NPCC/ $\mathrm{CaCO}_{3}$ sebesar $5 / 0 \mathrm{phr}, 5 / 5 \mathrm{phr}, 5 / 10 \mathrm{phr}, \mathrm{F} 3,5 / 15$ phr, dan 5/20 phr. Pengujian dan persyaratan mutu untuk sifat fisik dan mekanik dilakukan dengan metode sesuai SNI 0778:2009 Sol karet cetak.

\section{Komponding lateks}

Dispersi tunggal bahan aditif konsentrasi $50 \%$ dibuat dengan menggunakan ball mill dengan bantuan bola-bola keramik (Rathnayake et al., 2012; Nurbaya et al., 2012; Pipattananukul et al., 2014). Kompon lateks dibuat berdasarkan formula pada Tabel 1. 
Tabel 1. Formula sol sepatu dari lateks karet alam.

\begin{tabular}{|c|c|c|c|}
\hline \multirow{2}{*}{ No } & \multirow{2}{*}{ Bahan } & \multicolumn{2}{|c|}{ Jumlah, phr } \\
\hline & & Sol A & Sol B \\
\hline 1 & Lateks karet alam KKK 60\% & 100 & 100 \\
\hline 2 & Dispersi Sulfur 50\% & 3 & 3 \\
\hline 3 & Dispersi ZnO 50\% & 3 & 3 \\
\hline 4 & Dispersi ZDBC 50\% & 0,8 & 0,8 \\
\hline 5 & Dispersi Ionol 50\% & 2 & 2 \\
\hline 6 & Dispersi NPCC 50\% & 5 & 5 \\
\hline 7 & Dispersi $\mathrm{CaCO}_{3} 50 \%$ & 0 & 10 \\
\hline
\end{tabular}

\section{Penentuan waktu pemeraman optimum}

Kompon lateks yang telah dibuat diperam selama 24, 48, 72, dan 96 jam. Setiap periode waktu pemeraman, dilakukan uji bilangan kloroform dan derajat keasaman, untuk melihat tingkat kematangan kompon.

Uji bilangan kloroform dilakukan dengan cara mencampurkan kloroform dan kompon lateks dengan perbandingan massa 1:1, kemudian diaduk merata dan dibiarkan 2-3 menit. Setelah 2-3 menit, koagulan diuji dan diklasifikasikan sesuai tekstur yang dihasilkan. Bilangan kloroform dinyatakan sebagai berikut: (1) belum tervulkanisasi, (2) sedikit tervulkanisasi, (3) tervulkanisasi sedang, dan (4) tervulkanisasi penuh (Sasidharan et al., 2005).

\section{Metode pembuatan sol sepatu dari lateks karet alam}

Metode yang digunakan adalah cetak tuang dengan 3 metode. Pertama menggunakan teknik konvensional dengan pemanasan pada suhu rendah. Kompon lateks yang telah dituang dalam cetakan dikeringanginkan hingga kompon memadat, ke- mudian divulkanisasi dalam oven suhu $50^{\circ} \mathrm{C}$ selama 1 jam. Kedua, dengan menggunakan teknik yang dikembangkan oleh Lim (2009), yaitu dengan memanaskan pada suhu $150^{\circ} \mathrm{C}$ dan didinginkan secara natural. Ketiga, dengan mengembangkan metode Rancourt and Co. (2013), yaitu dengan menuangkan kompon lateks ke dalam cetakan yang terletak di dalam penangas air suhu $80 \pm 5^{\circ} \mathrm{C}$ dengan variasi waktu 1, 2, 3 dan 4 jam, kemudian memindahkannya ke dalam air suhu kamar selama 24 jam, dan dilanjutkan dengan vulkanisasi pada suhu $40 \pm 5^{\circ} \mathrm{C}$ selama $3 \times 24$ jam. Untuk setiap periode 24 jam vulkanisasi, sol sepatu direndam dalam air suhu kamar selama 24 jam. Dalam tahap ini, formula dasar sol A dan sol B digunakan untuk mengetahui keberhasilan teknik pembuatan, kekerasan, dan kuat tarik produk yang dihasilkan.

\section{Pengujian sol sepatu dari lateks karet alam}

Dengan menggunakan teknologi yang telah didapatkan pada tahap sebelumnya, penelitian dikembangkan dengan memvariasikan jumlah bahan pengisi $\mathrm{CaCO}_{3}$, sesuai dengan formula pada Tabel 2.

Tabel 2. Formula penelitian sol sepatu dari lateks karet alam.

\begin{tabular}{clccccc}
\hline \multirow{2}{*}{ No } & & \multicolumn{5}{c}{ Jumlah $\mathrm{NPCC} / \mathrm{CaCO}_{3}, \mathrm{phr}$} \\
\cline { 3 - 7 } & & $5 / 0$ & $5 / 5$ & $5 / 10$ & $5 / 15$ & $5 / 20$ \\
\hline 1 & Lateks karet alam KKK 60\% & 100 & 100 & 100 & 100 & 100 \\
2 & Dispersi Sulfur 50\% & 3 & 3 & 3 & 3 & 3 \\
3 & Dispersi ZnO 50\% & 3 & 3 & 3 & 3 & 3 \\
4 & Dispersi ZDBC 50\% & 0,8 & 0,8 & 0,8 & 0,8 & 0,8 \\
5 & Dispersi Ionol 50\% & 2 & 2 & 2 & 2 & 2 \\
6 & Dispersi NPCC 50\% & 5 & 5 & 5 & 5 & 5 \\
7 & Dispersi CaCO $30 \%$ & 0 & 5 & 10 & 15 & 20 \\
\hline
\end{tabular}


Tabel 3. Hasil uji bilangan kloroform dan $\mathrm{pH}$.

\begin{tabular}{cccccc}
\hline No. & $\begin{array}{c}\text { Perbandingan NPCC/ } \\
\mathrm{CaCO}_{3}(\mathrm{phr})\end{array}$ & Waktu (jam) & $\begin{array}{c}\text { Bilangan } \\
\text { Kloroform }\end{array}$ & $\mathrm{pH}$ & $\begin{array}{c}\text { Kekerasan } \\
\text { (Shore A) }\end{array}$ \\
\hline 1 & $5 / 0$ & 24 & 1 & 11,08 & 44,85 \\
2 & $5 / 0$ & 48 & 2 & 11,06 & 45,21 \\
3 & $5 / 0$ & 72 & 3 & 10,83 & 47,88 \\
4 & $5 / 0$ & 96 & 4 & 10,12 & 46,67 \\
5 & $5 / 10$ & 24 & 2 & 11,27 & 48,33 \\
6 & $5 / 10$ & 48 & 3 & 10,99 & 51,22 \\
7 & $5 / 10$ & 72 & 3 & 11,18 & 49,00 \\
8 & $5 / 10$ & 96 & 4 & 10,97 & 50,22 \\
\hline
\end{tabular}

Sol sepatu berbahan baku lateks karet alam belum memiliki standar mutu SNI, dan belum ditemukan standar internasional yang sesuai. Untuk itu, sol sepatu yang dihasilkan diuji dengan metode uji dan persyaratan mutu SNI 0778: 2009 Sol karet cetak. Persyaratan mutu yang dipilih adalah Mutu 3 sebagai berikut, kekerasan $55-80$ shore A, tegangan putus $\min 50 \mathrm{~kg} / \mathrm{cm}^{2}$, perpanjangan putus minimum $150 \%$, ketahanan retak lentur 150.000 kali tidak retak, bobot jenis maksimum $1,4 \mathrm{~g} / \mathrm{cm}^{3}$, ketahanan sobek minimum $35 \mathrm{~kg} / \mathrm{cm}^{2}$, ketahanan kikis DIN maksimum 350 $\mathrm{mm}^{3}$, dan perpanjangan tetap $50 \%$ maksimum $6 \%$. Morfologi produk yang dihasilkan juga diuji menggunakan SEM.

\section{HASIL DAN PEMBAHASAN \\ Penentuan Waktu Pemeraman Optimum}

Dari hasil uji pada Tabel 3, tampak bahwa kompon memasuki masa optimum kematangannya setelah 72 jam pemeraman untuk kompon dengan $\mathrm{NPCC} / \mathrm{CaCO}_{3} 5 / 0 \mathrm{phr}$, dan untuk kompon dengan $\mathrm{NPCC} / \mathrm{CaCO}_{3} 5 / 10 \mathrm{phr}$ telah matang setelah 48 jam, dan pada pemeraman 72 jam masih memiliki tingkat kematangan yang sedang, ditunjukkan dengan hasil nilai 3 pada uji bilangan kloroform. Uji kekerasan untuk kompon dengan NPCC/ $\mathrm{CaCO}_{3} 5 / 0 \mathrm{phr}$ memberikan kekerasan paling besar pada saat pemeraman $72 \mathrm{jam}$, yaitu sebesar 47,88 shore A. Hal ini sejalan dengan uji bilangan kloroform yang menyatakan bahwa setelah 72 jam kompon tersebut ada pada kondisi optimum kematangannya. Sementara pada kompon dengan $\mathrm{NPCC} / \mathrm{CaCO}_{3} 5 / 10$ phr, kekerasan tertinggi sebesar 51,22 shore A diperoleh pada pemeraman 48 jam, dan sedikit menurun pada pemeraman 72 jam, yaitu 49,00 shore A. Dari hasil ini maka pemeraman kompon lateks untuk penelitian akan dilakukan selama 72 jam.

Derajat keasaman kompon lateks selama pemeraman hingga 96 jam berada pada kisaran pH 10 - 11. Kondisi kompon lateks yang masih basa ini menunjukkan bahwa kompon lateks masih mengandung cukup banyak amonia untuk menjaga kompon lateks tetap stabil dan tidak menggumpal.

\section{Metode Pembuatan Sol Sepatu dari Lateks Karet Alam}

Metode konvensional dan metode Lim (2009) belum dapat menghasilkan produk yang baik. Hasil yang didapat dari metode konvensional adalah vulkanisat yang masih memiliki fase cair di bagian tengahnya. Hanya lapisan luar saja yang tampak tervulkanisasi. Sementara dengan metode Lim (2009), vulkanisat yang dihasilkan sangat berongga dan penuh dengan gelembung udara. Pengembangan metode Rancourt and Co. (2013) meunjukkan hasil yang beragam pada setiap variasi waktu pembentukannya, seperti tampak pada Tabel 4.

Faktor yang sangat berpengaruh pada tahap ini adalah jenis material, ketebalan dan kembangan cetakan sol sepatu. Jenis material berpengaruh pada laju pemanasan, ketebalan berpengaruh pada waktu pemanasan, sementara kembangan berpengaruh pada saat proses pelepasan sol sepatu dari cetakan. Sesuai hasil pada Tabel 4, kompon lateks sudah mulai memadat pada pemanasan 3 jam, namun masih kurang kuat ketika diangkat dari cetakan. Cetakan yang digunakan tidak didesain khusus untuk sol lateks, hanya memanfaatkan cetakan sol sepatu yang dibuat dari karet padat. Waktu tambahan 1 jam pemanasan ternyata cukup 
Tabel 4. Tahap pembentukan sol sepatu lateks formula dasar sol A.

\begin{tabular}{ccl}
\hline No. & Waktu Pembentukan & \multicolumn{1}{c}{ Hasil } \\
\hline 1 & 1 jam & Kompon masih cair \\
2 & 2 jam & Kompon mulai memadat \\
3 & 3 jam & $\begin{array}{l}\text { Kompon sudah memadat namun masih rapuh saat } \\
\text { diangkat dari cetakan } \\
\text { Kompon sudah memadat dan dapat diangkat dengan } \\
\text { baik dari cetakan }\end{array}$ \\
\hline
\end{tabular}

untuk meningkatkan kekerasan sol, terbukti pada waktu pemanasan 4 jam, kompon sol sudah dapat dilepaskan dengan baik dari cetakannya. Sol lateks hasil tahap pembentukan ini bersifat lentur dan lunak.

Pada saat pemanasan, air dari serum lateks menguap, meninggalkan pori-pori kecil pada sol lateks. Untuk menjaga pori-pori tersebut tetap ada, maka sol lateks segera direndam dalam air pada suhu kamar. Air akan mengisi pori-pori yang terbentuk. Perendaman juga berfungsi untuk menghilangkan sisa-sisa bahan kimia aditif yang tidak terikat.

Tahap selanjutnya adalah tahap vulkanisasi. Bahan pemvulkanisasi yang biasa dipakai untuk barang jadi karet alam adalah sulfur. Sulfur akan membentuk ikatan antar rantai polimer, pada gugus karbon isoprena seperti pada Gambar 1. Semakin banyak ikatan yang terbentuk diantara poli isoprena, semakin kuat polimer yang terbentuk, namun akan semakin mudah patah, begitu pula sebaliknya. Jumlah ikatan yang diharapkan adalah cukup untuk menghasilkan barang karet yang kuat dan elastis. Sehingga penambahan jumlah sulfur sangat berpengaruh pada pembentukan ikatan silang tersebut.

Tahap vulkanisasi dipadu dengan tahap pembentukan mikropori dan dilakukan secara berselang-seling selama 3 kali siklus. Saat vulkanisasi, air akan meninggalkan pori, ikatan sulfidik terbentuk diantara rantai polimer isoprena. Perendaman dalam air setelah vulkanisasi akan menjaga pori-pori tetap ada. Vulkanisasi pada suhu $40 \pm 5^{\circ} \mathrm{C}$ dipilih karena pemakaian zat pencepat vulkanisasi ZDBC yang memiliki karakteristik dapat membantu proses vulkanisasi pada suhu rendah, bahkan pada suhu kamar.

Formula sol sepatu yang dipakai pada tahap penentuan teknologi pembuatannya ini adalah formula dasar dengan $\mathrm{NPCC} / \mathrm{CaCO}_{3} 5 / 0 \mathrm{phr}$. Hasil uji menyatakan kuat tarik $134,75 \mathrm{~kg} / \mathrm{cm}^{2}$, perpanjangan putus $897,38 \%$, dan kekerasan 50,50 shore A. Nilai kuat tarik dan perpanjangan putus sudah memenuhi persyaratan SNI 0778:2009, namun kekerasannya masih di bawah syarat mutu. Dari hasil uji ini, maka formula penelitian dirancang untuk dapat meningkatkan sifat kekerasan produk dengan jalan menambahkan bahan pengisi $\mathrm{CaCO}_{3}$. Teknik pembuatan sol sepatu dengan tiga tahap ini dipilih untuk metode penelitian selanjutnya.

\section{Pengujian Sol Sepatu dari Lateks Karet Alam}

Hasil pengujian sifat fisik dan mekanik sol sepatu berdasarkan SNI 0778:2009 Sol karet cetak disajikan pada Tabel 5.

\section{Kekerasan}

Dari Tabel 5 tampak bahwa jumlah bahan pengisi yang ditambahkan dalam kompon lateks berpengaruh terhadap kekerasan. Kompon lateks

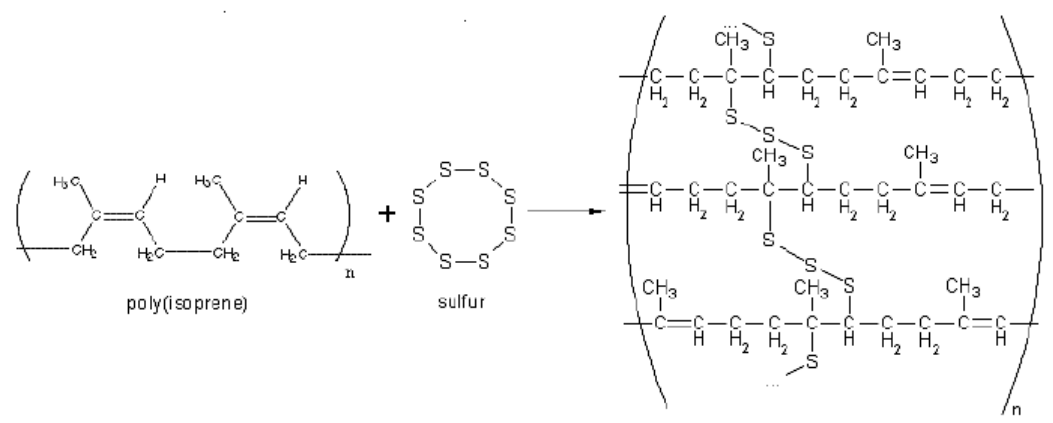

Gambar 1. Ikatan silang sulfidik antar rantai poliisoprena (Andriyanti dkk., 2010). 
yang diperkuat dengan bahan pengisi NPCC dan $\mathrm{CaCO}_{3}$ dengan jumlah phr yang berbeda, menunjukkan adanya perbedaan kekerasan. Semakin banyak penambahan bahan pengisi, kekerasan sol cenderung semakin meningkat. Hal ini juga didukung oleh penelitian Al-Mosawi et al. (2012) dan Poompradub et al. (2011) yang menyatakan bahwa kekerasan kompon karet alam dengan bahan pengisi $\mathrm{CaCO}_{3}$ meningkat seiring dengan penambahan jumlahnya. Penambahan bahan pengisi $\mathrm{NPCC} / \mathrm{CaCO}_{3}$ sebanyak $5 / 20 \mathrm{phr}$ memberikan nilai kekerasan paling tinggi, yakni sebesar 52,32 shore $\mathrm{A} . \mathrm{CaCO}_{3}$ dianggap sebagai bahan pengisi semi reinforcing yang dapat meningkatkan beberapa sifat vulkanisat (Gujel et al., 2014). Peningkatan substansial terhadap nilai kekerasan dihasilkan oleh peningkatan jumlah bahan pengisi yang ditambahkan. Semakin banyak dan semakin luas permukaannya, maka kompon yang dihasilkan akan semakin kaku. Kekerasan juga dapat menunjukkan kecenderungan yang sama terhadap nilai modulus suatu vulkanisat (Ahmed et al., 2012). Semakin banyak bahan pengisi yang ditambahkan, semakin keras vulkanisat yang dihasilkan, dan semakin tinggi pula nilai modulusnya (Sae-oei et al., 2009). Kekerasan sol merupakan faktor penting yang menentukan kualitas sepatu. Sol yang keras dan kaku menyebabkan sepatu tidak nyaman dipakai. Sebaliknya sol yang terlalu lunak kurang berfungsi sebagai pelindung telapak kaki.

\section{Tegangan putus}

Hasil tegangan putus pada Tabel 5 menunjukkan bahwa semakin besar jumlah bahan pengisi $\mathrm{CaCO}_{3}$ yang ditambahkan, nilai tegangan putus turun. Nuraya et al. (2012) juga melaporkan bahwa penambahan bahan pengisi yang semakin banyak dalam lateks dapat menurunkan sifat tegangan putus. Vulkanisat sol lateks karet alam dengan bahan pengisi $\mathrm{NPCC} / \mathrm{CaCO} 35 / 0 \mathrm{phr}$ memiliki tegangan putus tertinggi yakni sebesar $201,19 \mathrm{~kg} / \mathrm{cm}^{2}$. NPCC memiliki sifat menguatkan kompon karet, karena ukuran nano yang dimiliki. Semakin kecil ukuran partikel bahan pengisi mampu memberikan sifat tegangan putus yang lebih besar karena dapat meningkatkan jumlah interaksi antara karet dan bahan pengisi nano (Ahmed etal., 2012;Arun etal.,2010). Peningkatan penambahan jumlah bahan pengisi $\mathrm{CaCO}_{3}$ hingga jumlah tertentu pada vulkanisat karet padat mampu meningkatkan sifat tegangan putusnya. Namun pada vulkanisat lateks, fenomena ini berlangsung sebaliknya. Penurunan nilai tegangan putus dapat disebabkan oleh melemahnya ikatan antara bahan pengisi dan karet karena adanya efek pengenceran

Tabel 5. Sifat fisik dan mekanik sol lateks dari karet alam.

\begin{tabular}{|c|c|c|c|c|c|c|c|c|}
\hline \multirow{2}{*}{ No } & \multirow{2}{*}{ Parameter Uji } & \multirow{2}{*}{$\begin{array}{l}\text { Syarat } \\
\text { Mutu } 3\end{array}$} & \multirow{2}{*}{ Satuan } & \multicolumn{5}{|c|}{ Jumlah $\mathrm{NPCC} / \mathrm{CaCO}_{3}$ (phr) } \\
\hline & & & & $5 / 0$ & $5 / 5$ & $5 / 10$ & $5 / 15$ & $5 / 20$ \\
\hline 1 & Kekerasan & $55-80$ & Shore A & 44,79 & 46,33 & 50,40 & 48,18 & 52,32 \\
\hline 2 & Tegangan putus & $\min 50$ & $\mathrm{~kg} / \mathrm{cm}^{2}$ & 201,19 & 169,87 & 37,88 & 22,25 & 48,39 \\
\hline 3 & $\begin{array}{l}\text { Perpanjangan } \\
\text { putus }\end{array}$ & $\min 150$ & $\%$ & 766,14 & 648,03 & 418,37 & 221,52 & 444,62 \\
\hline 4 & $\begin{array}{l}\text { Ketahanan } \\
\text { retak lentur } \\
150.000 \text { kali }\end{array}$ & $\begin{array}{l}\text { tidak } \\
\text { retak }\end{array}$ & - & $\begin{array}{l}\text { tidak } \\
\text { retak }\end{array}$ & $\begin{array}{l}\text { tidak } \\
\text { retak }\end{array}$ & $\begin{array}{l}\text { tidak } \\
\text { retak }\end{array}$ & $\begin{array}{l}\text { tidak } \\
\text { retak }\end{array}$ & $\begin{array}{l}\text { tidak } \\
\text { retak }\end{array}$ \\
\hline 5 & Bobot jenis & $\begin{array}{l}\text { maks } \\
1,4\end{array}$ & $\mathrm{~g} / \mathrm{cm}^{3}$ & 0,92 & 0,93 & 1,00 & 1,07 & 1,06 \\
\hline 6 & $\begin{array}{l}\text { Ketahanan } \\
\text { sobek }\end{array}$ & $\min 35$ & $\mathrm{~kg} / \mathrm{cm}^{2}$ & $*$ & $*$ & 37,843 & 27,510 & 36,284 \\
\hline 7 & $\begin{array}{l}\text { Ketahanan } \\
\text { kikis DIN }\end{array}$ & $\begin{array}{l}\text { maks } \\
350\end{array}$ & $\mathrm{~mm}^{3}$ & 362,51 & 346,26 & 375,13 & 914,12 & 688,87 \\
\hline 8 & $\begin{array}{l}\text { Perpanjangan } \\
\text { tetap } 50 \%\end{array}$ & maks 6 & $\%$ & 2,40 & 2,15 & 2,45 & 3,84 & 3,67 \\
\hline
\end{tabular}

Keterangan: * pada waktu diuji sampel putus pada penjepit 
dan mulai terbentuknya aglomerat bahan pengisi di dalam matriks karet (Al-Mosawi et al., 2012; Ahmed et al., 2012; Poompradub et al., 2011). Aglomerat tersebut muncul karena distribusi bahan pengisi yang tidak homogen dalam matriks karet, sehingga menurunkan gaya tarik interfasial dan melemahkan tegangan putus (Fang et al., 2014). Saat vulkanisat diregangkan pada saat proses pengujian, agregat-agregat tersebut akan hancur dan mengakibatkan kegagalan awal vulkanisat (Nuraya et al., 2012).

\section{Perpanjangan putus}

Penambahan jumlah bahan pengisi $\mathrm{CaCO}_{3}$ mempengaruhi sifat perpanjangan putus sol lateks (Tabel 5). Semakin banyak bahan pengisi yang ditambahkan dalam kompon lateks karet alam maka perpanjangan putus menurun. Hal ini serupa dengan hasil penelitian yang telah dilakukan oleh Ahmed et al. (2012) yang memanfaatkan limbah marmer yang kaya akan $\mathrm{CaCO}_{3}$ sebagai bahan pengisi kompon karet alam. Vulkanisat karet alam tanpa bahan pengisi memiliki nilai perpanjangan putus yang lebih tinggi dibanding vulkanisat dengan tambahan bahan pengisi. Bahan pengisi dapat memberikan efek kaku terhadap rantai polimer serta dapat menurunkan regangan (Nuraya et al., 2012). Menurut Fang et al. (2014) sedikit NPCC yang ditambahkan tidak akan mengganggu rantai polimer untuk dapat memanjang dengan bebas. Ukuran partikel atau luas permukaan partikel, bersamaan dengan jumlah penambahannya, menentukan jarak inter-agregat yang mempengaruhi pembentukan jaringan dalam matriks polimer. Penurunan ini juga dapat disebabkan oleh efek dari pelarutan dan kerapatan ikatan silang (Sae-oei et al., 2009).

Menurut persyaratan SNI Sol karet cetak, perpanjangan putus ditetapkan sebesar 100\%. Oleh karena itu ditinjau dari jumlah bahan pengisi yang ditambahkan ke dalam kompon lateks, maka penambahan bahan pengisi sampai sebesar $25 \mathrm{phr}$ masih memberikan nilai perpanjangan putus yang baik dan memenuhi persyaratan SNI.

\section{Ketahanan retak lentur}

Pada Tabel 5 nampak bahwa penambahan bahan pengisi NPCC sebesar 5 phr, $\mathrm{CaCO}_{3}$ sampai dengan 20 phr, masih memberikan ketahanan retak lentur yang baik. Berdasarkan persyaratan ketahanan retak lentur pada SNI Sol karet cetak, maka semua formula memenuhi persyaratan.
Penambahan bahan pengisi ke dalam kompon lateks tentunya memiliki pe-ngaruh kepada elastisitas vulkanisat. Namun seperti umumnya, sol sepatu berbahan karet tahan terhadap 150.000 kali bengkukan, seperti sol ringan yang dibuat dari karet mikroseluler (Herminiwati \& Lestari, 2009; Herminiwati \& Sholeh, 2011).

\section{Bobot jenis}

Hasil pengukuran bobot jenis pada Tabel 5 sangat dipengaruhi oleh jumlah dan jenis bahan pengisi yang ditambahkan dalam kompon lateks. Penambahan bahan pengisi $\mathrm{CaCO}_{3}$ menghasikan nilai bobot jenis yang cenderung naik dan mampu memenuhi persyaratan SNI Sol karet cetak. Salah satu jenis sol adalah sol ringan, yaitu sol yang memiliki berat jenis kurang dari $1 \mathrm{~g} / \mathrm{cm}^{3}$ (Herminiwati \& Lestari, 2009). Proses pembuatan sol karet yang ringan dipengaruhi oleh jenis karet, bahan pengisi, dan teknologi pembuatannya (Yuniari, 2010). Dari penelitian ini, sol sepatu lateks dengan $\mathrm{NPCC} / \mathrm{CaCO}_{3} 5 / 0 \mathrm{phr}$ dan $5 / 5 \mathrm{phr}$ masuk di dalam jenis sol ringan. Bobot jenis juga dipengaruhi oleh struktur mikropori yang terbentuk dalam proses pembuatan sol lateks.

\section{Ketahanan sobek}

Tabel 5 menunjukkan bahwa penambahan jumlah $\mathrm{CaCO}_{3}$ sebesar 10 hingga 20 phr menghasilkan ketahanan sobek sekitar $35 \mathrm{~kg} / \mathrm{cm}^{2}$, mendekati syarat mutu SNI Sol karet cetak. Pada penambahan 0 dan phr $\mathrm{CaCO}_{3}$, nilai ketahanan sobek tidak dapat didefinisikan, karena pada saat proses pengujian cuplikan patah pada bagian penjepit. Sementara pada bagian tengah yang diinisiasi dengan sobekan justru tidak patah.

Dalam sol lateks, ketahanan sobek dapat dipengaruhi oleh jumlah dan ukuran mikropori yang terbentuk pada saat proses pembentukan dengan panas. Ukuran pori yang besar dan tidak merata mengakibatkan ketahanan sobek yang rendah. Faktor lain yang mempengaruhi ketahanan sobek adalah kerapatan ikatan silang dalam vulkanisat karet. Seperti diketahui bahwa nilai ketahanan sobek meningkat seiring dengan sedikit peningkatan kerapatan ikatan silang, hingga mencapai puncaknya, saat jumlah optimumnya tercapai (Gujel et al., 2014).

\section{Ketahanan kikis}

Sol lateks dari karet alam yang dihasilkan memiliki nilai ketahanan kikis yang sangat rendah. 

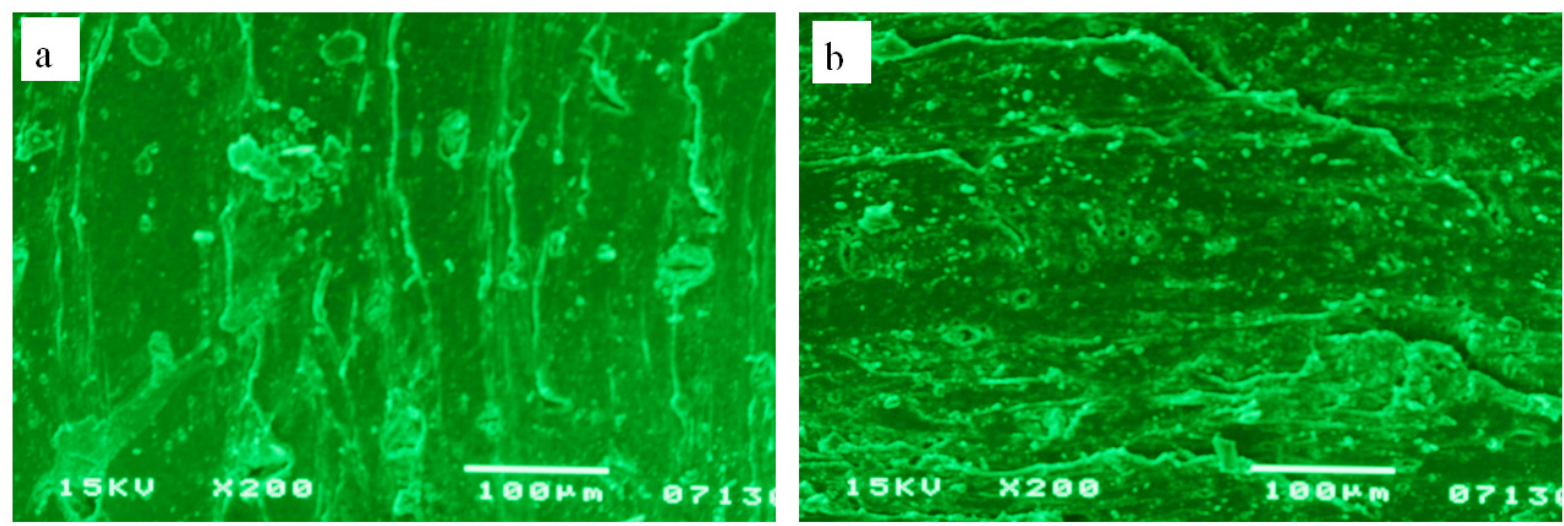

Gambar 2. Morfologi vulkanisat lateks (a) $\mathrm{NPCC} / \mathrm{CaCO}_{3} 5 / 0 \mathrm{phr}$ (b) $\mathrm{NPCC} / \mathrm{CaCO}_{3} 5 / 15 \mathrm{phr}$.

Dari data pada Tabel 5, hanya formulasi dengan $\mathrm{NPCC} / \mathrm{CaCO}_{3} 5 / 5 \mathrm{phr}$ (ketahanan kikis 346,26 $\mathrm{mm}^{3}$ ) yang mampu memenuhi persyaratan SNI Sol karet cetak. Semakin banyak bahan pengisi yang ditambahkan akan mampu menaikkan kekerasan produk, namun sangat signifikan menurunkan ketahanan kikis sol lateks tersebut.

Ketahanan kikis vulkanisat karet yang menggunakan bahan pengisi pada dasarnya ditentukan oleh karakterisasi bahan pengisi, khususnya pada sifat morfologi dan reaktivitas permukaannya. Selain itu juga dapat disebabkan oleh dispersi dan distribusi partikel bahan pengisi yang tidak homogen di dalam matriks karet (Hasan et al., 2012). Seperti yang telah dijelaskan sebelumnya, dispersi bahan pengisi dalam matriks karet sangat mempengaruhi sifat produk yang dihasilkan. Adanya agregasi bahan pengisi dalam matriks menyebabkan kerapuhan pada produk, sebagai akibatnya interaksi antara partikel dan matriks berkurang (Fang et al., 2014). Agregasi tersebut dapat dilihat pada hasil uji morfologi vulkanisat sol dari lateks.

\section{Perpanjangan tetap 50\%}

Nilai perpanjangan tetap $50 \%$ yang dipersyaratkan pada SNI Sol karet cetak mampu dipenuhi untuk semua formula dalam penelitian (Tabel 5). Penambahan bahan pengisi sedikit menaikkan nilai perpanjangan tetap, namun formulasi dengan NPCC/CaCO $35 / 5 \mathrm{phr}$ memiliki nilai perpanjangan tetap terkecil, yaitu $2,15 \%$.

Berdasarkan sifat mekanik yang diberikan, maka formula sol lateks dengan $\mathrm{NPCC} / \mathrm{CaCO}_{3}$ $5 / 5 \mathrm{phr}$ merupakan formula terbaik dan memenuhi seluruh syarat mutu SNI Sol karet cetak kecuali kekerasannya.

\section{Pengujian morfologi}

Pada Gambar 2a tampak ruang-ruang kosong pada matriks karet dan pada Gambar 2b, ruang-ruang kosong tersebut telah terisi oleh agregat-agregat $\mathrm{CaCO}_{3}$. Semakin banyak jumlah $\mathrm{CaCO}_{3}$ yang ditambahkan dalam kompon lateks, maka matriks karet akan semakin dipenuhi oleh dispersi bahan pengisi tersebut. Titik-titik putih merepresentasikan partikel bahan pengisi dan warna dasar merepresentasikan matriks karet alam (Poompradub et al., 2011). Jika $\mathrm{CaCO}_{3}$ tidak dapat terdistribusi dengan baik dalam kompon lateks, ataupun tidak terikat sempurna dalam matrik vulkanisat, maka akan terbentuk agregat bahan pengisi. Aglomerasi bahan pengisi menurunkan efektivitas gaya tarik interfasial antara partikel bahan pengisi dan matriks karet serta menyebabkan terjadinya void di antara agregat dan matriks karet. Hal ini lebih jauh dapat menyebabkan agregat $\mathrm{CaCO}_{3}$ beraksi sebagai titik pusat tekanan ketika ditarik/diregangkan, sehingga mampu menurunkan sifat mekaniknya (Nuraya et al., 2012; Fang et al., 2014). $\mathrm{CaCO}_{3}$ hanya menambah kekerasan dengan meningkatkan tegangan permukaan, namun tidak secara signifikan menaikkan sifat mekaniknya. Justru sebaliknya, penambahan $\mathrm{CaCO}_{3}$ lebih dari $5 \mathrm{phr}$ cenderung menurunkan sifat sol sepatu lateks.

\section{KESIMPULAN}

Pembuatan sol sepatu dari lateks karet alam dapat dilakukan dengan metode cetak tuang melalui tiga tahapan proses. Tahapan tersebut adalah pembentukan dalam penangas air suhu $80 \pm 5^{\circ} \mathrm{C}$ selama 4 jam, tahap pembentukan mikropori dengan perendaman dalam air suhu kamar selama 24 jam, dan dilanjutkan dengan vulkanisasi pada 
suhu $40 \pm 5^{\circ} \mathrm{C}$ selama $3 \times 24$ jam, berselang dengan perendaman. Bahan pengisi NPCC memberikan sifat fisik dan mekanik yang sangat baik pada produk yang dihasilkan, sedangkan penambahan bahan pengisi $\mathrm{CaCO}_{3}$ dapat meningkatkan kekerasan, namun cenderung menurunkan sifat mekanik yang lain. Formula terbaik untuk sol sepatu dari lateks karet alam dalam penelitian ini adalah formula dengan penambahan bahan pengisi $\mathrm{NPCC} / \mathrm{CaCO}_{3} 5 / 5 \mathrm{phr}$. Formula terbaik mempunyai sifat fisik mekanik sebagai berikut, kekerasan 46,33 shore A, tegangan putus 169,87 $\mathrm{kg} / \mathrm{cm}^{2}$, perpanjangan putus $648,03 \%$, tidak retak ketika dikenai bengkukan 150.000 kali, bobot jenis $0,93 \mathrm{~g} / \mathrm{cm}^{3}$, ketahanan kikis DIN 346,26 $\mathrm{mm}^{3}$, dan perpanjangan tetap $50 \%$ sebesar $2,15 \%$. Pengujian morfologi menunjukkan bahwa distribusi partikel bahan pengisi $\mathrm{CaCO}_{3}$ tidak homogen di dalam matriks karet, sehingga hal ini dapat menurunkan sifat tegangan putus dan ketahanan kikis sol lateks.

\section{UCAPAN TERIMA KASIH}

Penulis mengucapkan terimakasih kepada Kepala BBKKP atas dana yang diberikan untuk penelitian ini, serta kepada Ibu Ihda Novia dan Ibu Dwi Wahini atas ide, bantuan, dan kerjasamanya selama proses penelitian dan penulisan makalah ini.

\section{DAFTAR PUSTAKA}

Ahmed, K., Nizami, S. S., Raza, N. Z., \& Mahmood, K. (2012). Mechanical, swelling, and thermal aging properties of marble sludge-natural rubber composites. International Journal of Industrial Chemistry, 3(1), 1-12.

Al-Mosawi, A. I., Ali, M. M., \& Mohmmed, J. H. (2012). Experimental approach to mechanical properties of natural rubber mixing with calcium carbonate powder. International Journal of Physical Sciences, 7(49), 6280-6282.

Andriyanti, W., Darsono, \& Faisal, W. (2010). Kajian metode vulkanisasi lateks karet alam berbasis nitrosamin dan protein alergen. Dalam Prosiding PPI-PDIPTN. Yogyakarta, Indonesia: BATAN.

Arun, K. J., Francis, P. J., \& Joseph, R. (2010). Mechanical properties of NR latex-nano silica composites, optoelectronics and advanced materials-rapid communication. $O A M-R C, 4,1520-1525$.

BSN (Badan Standardisasi Nasional). (2009). SNI 0778: 2009 Sol karet cetak. Jakarta, Indonesia: BSN.

Fachry, A. R., Sari, T. I., Putra, B. A., \& Kristianto, D. A. (2012). Pengaruh penambahan filler kaolin terhadap elastisitas dan kekerasan produk souvenir dari karet alam (Hevea brasiliensis). Dalam Seminar Nasional Teknologi Oleo dan Petrokimia Indonesia (TOPI). Pekanbaru, Indonesia: Universitas Riau.

Fang, Q., Song, B., Tee, T., Sin, L. T., Hui, D., \& Bee, S. (2014). Investigation of dynamic characteristics of nano-size calcium carbonate added in natural rubber vulcanizate. Composites: Part B, 60, 561567.

Gujel, A. A., Bandeira, M., Giovanela, M., Carli, L. N., Brandalise, R. N., \& Crespo, J. S. (2014). Development of bus body rubber profiles with additives from renewable sources: Part II-Chemical, physical-mechanical and aging characterization of elastomeric compositions. Materials and Design, 53, 1119-1123.

Hasan, H. H., Ateia, E., Darwish, N. A., Halim, S. F., \& Abd El-Azis, A. K. (2012). Effect of filler concentration on the physico-mechanical properties of super abrasion furnace black and silica loaded styrene butadiene rubber. Materials and Design, 34, 533-540.

Herminiwati, H., \& Lestari S. B. P. (2009). Pengaruh penambahan bahan pengisi alumunium silikat dan bahan pengembang azodicarbonamide dalam pembuatan karet mikroseluler untuk sol ringan. Majalah Kulit, Karet, dan Plastik, 25(1), 31-38.

Herminiwati, H., \& Sholeh, M. (2011). Aplikasi karet mikroseluler untuk sol ringan alas kaki. Majalah Kulit, Karet, dan Plastik, 27(1), 23-30.

Lim, G. C. (2009). U.S. Patent No. 20090289394. Washington, USA: U.S. Patent and Trademark Office.

Nuraya, A. S. S., Baharin, A., Azura, A. R., Hakim, M. H. M. R., Mazlan, I., Adnan, M., \& Nooraziah, A. A. (2012). Reinforcement of prevulcanised natural rubber latex films by banana stem powder and comparison with silica and calcium carbonate. Journal of Rubber Research, 15(2), 124-140.

Nurhayat, W. (2014). Harga karet dunia Rp 16 ribu /kg petani hanya dapat $R p \quad 6$ ribu/kg, http://finance. detik.com/read/2014/05/09/144636/2578360/103 6/harga-karet-dunia-rp-16-ribu-kg-petani-hanyadapat-rp-6000-kg, diakses tanggal 29 Juni 2014.

Pipattananukul, N., Ariyawiriyanan, W., \& Kawahara, S. (2014). Thermal behaviour of vulcanized deproteinzed natural rubber nano-composites. Energy Procedia, 56, 634-640.

Poompradub, S., Luthikaviboon, T., Linpoo, S., Rojanathanes, R., \& Prasassarakich, P. (2011). Improving oxidation stability and mechanical properties of natural rubber vulcanizates filled with calcium carbonate modified by gallic acid. Polymer Bulletin, 66(7), 965-977.

Rancourt \& Co. (2013). The best soles in the worldLactae hevea, http://www.rancourtandcompany. 
com/blog/2013/02/12/the-best-rubber-soles-inthe-world-lactae-hevea/ diakses 28 Maret 2013.

Rathnayake, W. G. I. U., Ismail, H., Baharin, A., Darsanasiri, A. G. N. D., \& Rajapakse, S. (2012). Synthesis and characterization of nano silver based natural rubber latex foam for imparting antibacterial and anti-fungal properties. Polymer Testing, 31, 586-592.

Sae-oui, P., Sirisinha, C., \& Thaptong, P. (2009). Utilization of limestone dust waste as filler in natural rubber. Journal of material cycles and waste management, 11(2), 166-171.
Sasidharan, K. K., Joseph, R., Palaty, S., Gopalakrishnan, K. S., Rajamal, G., \& Pillai, P. V. (2005). Effect of the vulcanization time and storage on the stability and physical properties of sulfur-prevulcanized natural rubber latex. Journal of Applied Polymer Science, 97, 1804-181.

Yuniari, A. (2010). Pengaruh penggunaan nitril butadiene rubber dan pale crepe pada pembuatan sol karet untuk sepatu pengaman. Majalah Kulit, Karet, dan Plastik, 26(1), 01-08. 